\title{
The synergistic effect between graphene oxide nanocolloids and silicon dioxide nanoparticles for gallic acid sensing
}

\author{
Chrys O. Chikere ${ }^{1} \cdot$ Nadimul Haque Faisal ${ }^{2} \cdot$ Paul Kong Thoo Lin $^{1} \cdot$ Carlos Fernandez ${ }^{1}$
}

Received: 10 January 2019 / Revised: 28 March 2019 / Accepted: 29 March 2019 / Published online: 10 May 2019

(C) The Author(s) 2019

\begin{abstract}
For the first time, the synergistic effect of graphene oxide nanocolloids (nano-GO) and silicon dioxide (silica) nanoparticles $\left(\mathrm{SiO}_{2}\right.$-nanoparicles) has been used to modify a glassy carbon electrode (GCE) for the determination of gallic acid (GA). The modified electrode surface was characterised by using scanning electron microscopy (SEM), energy-dispersive X-ray spectroscopy (EDXA) and Fourier transform infrared spectroscopy (FTIR). The electrochemical behaviour of the modified electrode was then studied, using cyclic voltammetry (CV) and differential pulse voltammetry (DPV), showing that the electrode was sensitive to GA in a concentration range of $6.25 \times 10^{-6}$ to $1.0 \times 10^{-3} \mathrm{~mol} \mathrm{~L}^{-1}$, with a correlation coefficient $R^{2}$ of 0.9956 and a limit of detection of $2.09 \times 10^{-6} \mathrm{~mol} \mathrm{~L}^{-1}(\mathrm{~S} / \mathrm{N}=3)$. The proposed method was successfully used for the determination of GA in red wine, white wine and orange juice, with recoveries of 102.3, 95.4 and $97.6 \%$, respectively.
\end{abstract}

Keywords Graphene oxide nanocolloids $\cdot$ Gallic acid $\cdot \mathrm{SiO}_{2}$ nanoparticles $\cdot$ Electrochemistry $\cdot$ Cyclic voltammetry $\cdot$ Differential pulse voltammetry

\section{Introduction}

Gallic acid (2,3,4-trihydroxybenzoic acid) (GA) is a naturally occurring phenolic compound in plants and is a natural antioxidant with several biological activities. The compound has shown its capacity as a reducing agent in the pharmaceutical industry and also as a homoeopathic drug that can be found in tea, red wine, fruits (bananas, blueberries, grapes), beverages and several medicinal plants [1]. In the pharmaceutical industry, it is widely used as a reducing agent in products like Dermatol, Airol and bismuth salts of gallic acid [2]. Several studies had shown GA to have anti-carcinogenic, antimutagenic and anti-oxidative properties [3]; hence, it is recommended usage as an antioxidant in human diet. This is because it can reduce the risk of disease development, by the

Electronic supplementary material The online version of this article (https://doi.org/10.1007/s10008-019-04267-9) contains supplementary material, which is available to authorized users.

Carlos Fernandez

c.fernandez@rgu.ac.uk

1 School of Pharmacy and Life Sciences, Robert Gordon University, Aberdeen, UK

2 School of Engineering, Robert Gordon University, Aberdeen, UK prevention or slowing down of molecular oxidation in the body [4], known as oxidative stress. Furthermore, oxidative stress has been linked to human diseases like Alzheimer's disease, cardiovascular diseases, Parkinson's disease, diabetes and cancer $[5,6]$.

With the increasing importance of antioxidants in our diets and our health, especially natural antioxidants like vitamins, carotenoids and phenolic or flavonoid compounds in the reduction of oxidative stress, many in vitro chemically based assays have been developed for the determination of the capacity of these antioxidants. The study of antioxidant properties has been mainly carried out by spectrophotometric methods [7, 8], chromatographic [9, 10], flow injectionchemiluminescence [11] and electrochemical methods [12-14]. However, the main drawbacks to the chromatographic and spectrophotometric methods have been the cost of equipment, coupled with the extensive time-consuming sample preparation procedures as well as the use of expensive and toxic reagents which are detrimental to the environment.

Amongst all the available methods, electrochemical techniques have generated a lot of interest due to their many advantages, including being fast, sensitive, selective, inexpensive and portable, with little or no sample pre-treatment. Furthermore, they are amenable for miniaturisation and do not suffer from colour interference. Many different 
electrochemical methods have been developed in literature for the determination of polyphenols [15-19]. The most common electrochemical techniques for the determination of GA have been $\mathrm{CV}$ and differential pulse voltammetry (DPV), which were also used in this work.

Nanomaterials such as $\mathrm{SiO}_{2}$ and $\mathrm{TiO}_{2}$ have been previously employed in the modification of carbon paste electrodes [14, $20]$ for the determination of GA with relatively low limits of detection (LOD) of $2.5 \times 10^{-7} \mathrm{~mol} \mathrm{~L}^{-1}$ and $9.4 \times 10^{-7} \mathrm{~mol}$ $\mathrm{L}^{-1}$, respectively. Although metal oxide nanoparticles with graphite or regular graphene oxide sheet electrodes have been used for gallic acid determination, there has been no attempt in using graphene oxide nanocolloids. Aqueous graphene oxide nanocolloids having high charge density originating from their high edge-to-area ratios are significantly more stable than the regular graphene oxide.

Here in this work and for the first time, the synergetic effect of graphene oxide nanocolloids and $\mathrm{SiO}_{2}$ nanoparticles has been used to modify a glassy carbon electrode, by a dropcasting method in the determination of the antioxidant capacity of gallic acid. The modified electrode was also used to demonstrate selectivity by the simultaneous determination of gallic acid and uric acid, with a successful determination of GA in orange juice, red wine and white wine.

\section{Experimental}

\section{Reagents and materials}

Gallic acid (anhydrous, molar mass $170.12 \mathrm{~g} \mathrm{~mol}^{-1}$ ), potassium chloride (analytical grade $\geq 99.8 \%$ ), graphene oxide nanocolloids (nano-GO), tetraethyl orthosilicate (TEOS) and aqueous ammonia $(28-30 \%)$, and potassium hexacyanoferrate (II) trihydrate (analytical grade $\geq 99.95 \%$ ) were purchased from Sigma Aldrich (London, UK). Analytical grade salts of sodium dihydrogen orthophosphate and disodium hydrogen orthophosphate, potassium nitrate, sodium hydroxide and phosphoric acid were from Merck (Darmstadt, Germany). All the reagents unless stated were of the highest purity, with no further purification required. All solutions were freshly prepared with doubly distilled water with a resistance value of $18.2 \mathrm{M} \Omega \mathrm{cm}$. All the stock solutions used were protected from light and refrigerated at about $4{ }^{\circ} \mathrm{C}$. Wine samples were commercially available brands (Casillero Del Diablo Cabernet Sauvignon and Sauvignon Blanc) and the orange juice (Innocent Smooth Orange Juice) from ASDA (UK).

\section{Apparatus and methods}

All the electrochemical measurements were carried out using an Ivium vertex one potentiostat-galvanostat and analysed using Iviumsoft software (Eindhoven, Netherlands). A standard three-electrode system was employed to perform all the electrochemical experiments. The cell consisted of a commercially available glassy carbon working electrode with a diameter of $\varnothing=0.5 \mathrm{~cm}$, a $\mathrm{KCl}$ saturated $\mathrm{Ag} / \mathrm{AgCl}$ reference electrode and a platinum counter electrode, purchased from BASi (West Lafayette, USA). The 0.1-mol L ${ }^{-1}$ phosphate buffer solution (PBS) was prepared by mixing the appropriate volumes of $0.2 \mathrm{~mol} \mathrm{~L}^{-1} \mathrm{Na}_{2} \mathrm{HPO}_{4}$ and $0.2 \mathrm{~mol} \mathrm{~L}^{-1} \mathrm{NaH}_{2} \mathrm{PO}_{4}$ to $50 \mathrm{~mL}$, then diluted to $100 \mathrm{~mL}$ with deionised water. Meanwhile, the measurement of the $\mathrm{pH}$ conditions was carried out with a Fisher Scientific (Loughborough, UK) Mettler Toledo Benchtop $\mathrm{pH}$ meter. The phosphate buffer solutions with $\mathrm{pH}$ values 2, 4, 6 and 8 were prepared by adjusting the ratio of $\mathrm{Na}_{2} \mathrm{HPO}_{4}$ and $\mathrm{NaH}_{2} \mathrm{PO}_{4}$, whilst using $1 \times 10^{-2} \mathrm{~mol}$ $\mathrm{L}^{-1}$ phosphoric acid to reduce the $\mathrm{pH}$ and $0.1 \mathrm{~mol} \mathrm{~L}^{-1}$ sodium hydroxide to increase the $\mathrm{pH}$. Ultrasonication of the polished electrode was done by using a Fisher Scientific ultrasonication bath from Fisher Scientific (Loughborough, UK). All the potentials quoted in the experiments were relative to an $\mathrm{Ag} / \mathrm{AgCl}$ reference electrode. Statistical analysis of all data was carried out with MS Excel and all the voltammograms and graphs produced using Origin Pro 8 software.

\section{Synthesis of $\mathrm{SiO}_{2}$ nanoparticles}

The synthesis of $\mathrm{SiO}_{2}$ nanoparticles was carried out according to Venkatathri [21], where aqueous ammonia $(3.14 \mathrm{~mL})$ was added to a solution of ethanol $(74 \mathrm{~mL})$ and deionised water $(10 \mathrm{~mL})$. Then, tetraethyl orthosilicate (TEOS) $(6 \mathrm{~mL})$ was added to the previously prepared solution with vigorous stirring at room temperature. This is because sol-gel synthesis is performed at low temperatures, typically at room temperature. The reaction mixture was stirred for $1 \mathrm{~h}$, to yield uniform silica spheres in a sol. The latter was centrifuged, and the residue was washed with distilled water and ethanol three times followed by drying at room temperature to yield the $\mathrm{SiO}_{2}$ nanoparticles.

\section{Preparation of the electrodes}

The synthesised $\mathrm{SiO}_{2}$ nanoparticles were dispersed in a solution of graphene oxide nanocolloids at a concentration of 1 $\mathrm{g} / \mathrm{L}$, being the amount of the nanoparticles with the best result. Then, the mixture was sonicated for about $1 \mathrm{~h}$, to provide a uniform dispersion of $\mathrm{SiO}_{2}$ nanoparticles in the $\mathrm{GO}$ nanocolloids solution. Prior to each experiment, the GCE was polished on a felt lapping pad purchased from Alvatek (Tetbury, UK), with $0.1,0.3$ and $0.05 \mu \mathrm{m}$ alumina paste to a mirror finish. Subsequently, the electrode was rinsed with water, and finally, an ultrasonic treatment in water and ethanol was applied, respectively, to remove any particles of alumina slurry on the electrode. 
A mixture of graphene oxide $(2 \mathrm{mg} / \mathrm{mL})$ solution and $\mathrm{SiO}_{2}$ nanoparticles $(1 \mathrm{mg} / \mathrm{mL})$ in deionised water was prepared by sonicating both compounds for $1 \mathrm{~h}$. After that, the GCE was modified with the prepared solution by drop casting with $5 \mu \mathrm{L}$ of the suspended nano-graphene oxide- $\mathrm{SiO}_{2}$ nanoparticles directly on to the surface of the electrode. The electrode, modified with GCE-nano-graphene oxide- $\mathrm{SiO}_{2}$ nanoparticles, was then left to dry at room temperature. GCE-SiO ${ }_{2}$ and GCE-GO were prepared by drop casting $\mathrm{SiO}_{2}$ and $\mathrm{GO}$, respectively, on the surface of the GCE. The electrolytes used for the experiment were thoroughly deoxygenated by bubbling/purging with high purity nitrogen gas prior to each experiment.

\section{Electrochemical measurements}

Electrochemical analysis of GA at the surface of the nanoGO-SiO ${ }_{2}$ nanoparticle-modified GCE was carried out in $0.1 \mathrm{~mol} \mathrm{~L}^{-1} \mathrm{pH} 2.0$ phosphate buffer solution. The $\mathrm{CV}$ was scanned within a range of $0.0 \mathrm{~V}$ to $+1.8 \mathrm{~V}$ at a scan rate of 100 $\mathrm{mVs}^{-1}$. The differential pulse voltammograms were recorded in a potential range between 0.0 and $+1.2 \mathrm{~V}$ with a pulse amplitude of $0.08 \mathrm{~V}$ and pulse period of $0.2 \mathrm{~s}$.

$\mathrm{CV}$ was used to study $1 \times 10^{-3} \mathrm{~mol} \mathrm{~L}^{-1}$ potassium ferrocyanide $\left[\mathrm{Fe}(\mathrm{CN})_{6}\right]^{3-}$ on the surface of the electrodes, swept over a potential range of -0.6 to $0.6 \mathrm{~V}$ at different scan rates. The voltammograms recorded were used for the determination of the electroactive areas of nano-GO- $\mathrm{SiO}_{2}$ nanoparticle GCE, nano-GO-GCE and the bare GCE electrode.

Electrochemical impedance spectroscopy was used as a technique to provide information on the impedance changes on the bare and modified GCE electrode surfaces and the Nyquist plots were recorded. The EIS measurement was performed in the frequency range of $100 \mathrm{kHz}-0.01 \mathrm{~Hz}$ (50 points within the frequency range) and a potential of $0.4 \mathrm{~V}$ in $0.1 \mathrm{~mol}$ $\mathrm{L}^{-1} \mathrm{KCl}$ containing $5 \mathrm{mmol} \mathrm{L}^{-1}\left[\mathrm{Fe}(\mathrm{CN})_{6}\right]^{3-/ 4-}$ redox solution.

Adsorption time of GA on to the modified electrode was studied by DPV measurement and the voltammograms for the determination $1 \times 10^{-3} \mathrm{~mol} \mathrm{~L}^{-1} \mathrm{GA}$, recorded every minute for $6 \mathrm{~min}$.

The selectivity of the modified electrode was investigated by mixing $5 \mathrm{~mL}$ of a $0.48 \mathrm{mmol} \mathrm{L}^{-1} \mathrm{GA}$ and $5 \mathrm{~mL}$ of a $0.36 \mathrm{mmol} \mathrm{L}^{-1}$ uric acid in $0.1 \mathrm{~mol} \mathrm{~L}^{-1}$ phosphate buffer solution of $\mathrm{pH} 2.0$ and then cyclic voltammograms are recorded at room temperature, with a scan rate of $100 \mathrm{mVs}^{-1}$.

The reproducibility and repeatability of the method were tested by measuring eight replicates of $10 \mathrm{~mL}, 1 \times 10^{-3} \mathrm{~mol}$ $\mathrm{L}^{-1} \mathrm{GA}$ in a $0.1 \mathrm{~mol} \mathrm{~L}^{-1}$ phosphate buffer of $\mathrm{pH} 2.0$, using three different nano-GO-SiO ${ }_{2}$ nanoparticle-modified GCEs, and the DPVs are recorded.

The interference of foreign ions in the determination of GA was investigated, by adding $5 \mathrm{~mL}$ of $1 \times 10^{-3} \mathrm{~mol} \mathrm{~L}^{-1}$ solution of GA into $5 \mathrm{~mL}$ of $0.1 \mathrm{~mol} \mathrm{~L}^{-1}$ solutions containing $\mathrm{K}^{+}, \mathrm{Ca}^{2+}$, $\mathrm{Fe}^{3+}$ and $\mathrm{Na}^{+}$ions, whilst $5 \mathrm{~mL}$ of $1 \times 10^{-3} \mathrm{~mol} \mathrm{~L}^{-1}$ solution of ascorbic acid, caffeine and caffeic acid, respectively, were added to $1 \times 10^{-3} \mathrm{~mol} \mathrm{~L}^{-1}$ solutions of GA and vigorously stirred for $2 \mathrm{~min}$ followed by recording of the DPV.

\section{Preparation and determination of real samples}

The GA content of the real samples of commercially available orange juice, red and white wine was analysed by using the voltammetric standard addition method. Triplicates of $10 \mathrm{~mL}$ of the real samples (orange juice, red and white wine) were used as blanks. Standard addition of aliquots of $1 \times 10^{-2} \mathrm{~mol}$ $\mathrm{L}^{-1} \mathrm{GA}$ was then added to the electrochemical cell and vigorously stirred using a magnetic stirrer for 2 min, after each addition of the aliquot of GA and the voltammograms recorded.

\section{Results and discussion}

\section{Characterisation of the prepared nano-GO-SiO nanoparticles}

The nano-GO-SiO ${ }_{2}$ nanoparticle-modified electrode was characterised using SEM (scanning electron microscopy). The SEM uses a focused beam with high-energy electrons that generate different signals on the surface of electrode. These signals reveal information about the external morphology, the chemical composition and the visuals of the crystalline structure of the $\mathrm{SiO}_{2}$ nanoparticles. This shows the spherical morphology and homogenous size distribution (Fig. 1a) of the synthesised $\mathrm{SiO}_{2}$ nanoparticles. The spherical particles had sizes ranging from 100 to about $200 \mathrm{~nm}$, as can be seen in Fig. $1 \mathrm{a}$, whilst Fig. $1 \mathrm{~b}$ shows the morphology of the nanoGO-SiO ${ }_{2}$ nanoparticle mixture on the surface of the GCE.

As reported earlier by Tashkhourian and Nami-Ana [14] and Wang et al. [22], the nanosized $\mathrm{SiO}_{2}$ nanoparticles as seen on the SEM images creates a large active surface area, better transmission performance and high accumulation efficiency.

Fourier transform infrared spectroscopy (FTIR) was also used for the characterisation of the $\mathrm{SiO}_{2}$ nanoparticles, nano$\mathrm{GO}$ and nano- $\mathrm{GO}-\mathrm{SiO}_{2}$ nanoparticle combination, to show the decoration of the $\mathrm{SiO}_{2}$ nanoparticles on the nano-GO. The spectra were recorded as can be seen in Fig. 2, where the nano-GO spectrum and $\mathrm{SiO}_{2}$ nanoparticles agreed with other works. The bands around 3250 and $1408 \mathrm{~cm}^{-1}$ were attributed to the deformed $-\mathrm{OH}$ bonds of graphene oxide and the $\mathrm{CO}-\mathrm{H}$ groups, respectively. Meanwhile, the bands centred around $1039 \mathrm{~cm}^{-1}$ were associated with the $\mathrm{C}-\mathrm{O}$ bond stretching and the $1724 \mathrm{~cm}^{-1}$ was then associated to the stretching vibration of the carbonyl or carboxyl groups [23, 24]. With the mixing of the $\mathrm{SiO}_{2}$ nanoparticles, the characteristic peaks of silica nanospheres were formed on the surface of the nano- 

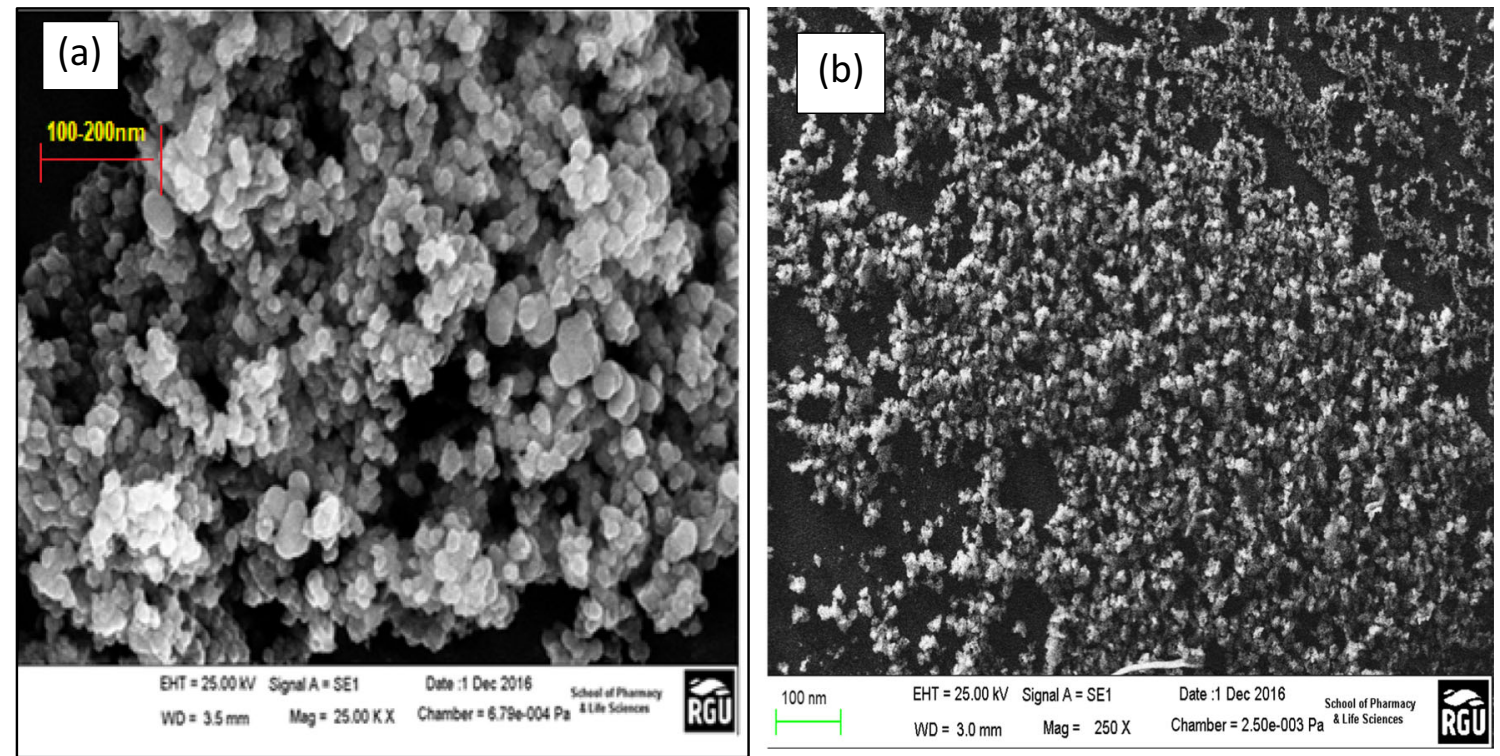

Fig. 1 a The SEM image $\mathrm{SiO}_{2}$ nanoparticles showing the morphology of the nanospheres and the different spectrums used for the EDX, with $\mathbf{b}$ showing the morphology of the nano- $\mathrm{GO}-\mathrm{SiO}_{2}$ nanoparticles mixture on the $\mathrm{GCE}$

GO, where the peaks at 533 and $795 \mathrm{~cm}^{-1}$ are attributed to $\mathrm{Si}-$ $\mathrm{O}-\mathrm{Si}$ bending and symmetric stretching vibration, respectively. The main strong and broad band at $1066 \mathrm{~cm}^{-1}$ with a bit of shoulder is usually assigned to the transverse (TO) and longitudinal optical (LO) modes of the $\mathrm{Si}-\mathrm{O}-\mathrm{Si}$ asymmetric stretching vibrations $[25,26]$. On the other hand, the band observed at $953.59 \mathrm{~cm}^{-1}$ on the $\mathrm{SiO}_{2}$ IR image attributed to the silanol group ( $\mathrm{Si}-\mathrm{OH})$ is seen to have diminished at the combination of nano-GO and $\mathrm{SiO}_{2}$ nanoparticles. This diminished band can be attributed to the hydrogen bonding between the silanol groups $(\mathrm{Si}-\mathrm{OH})$ to the $\mathrm{GO}$ nanocolloids and the GA. Furthermore, there was no significant change in the area between 1575 and $1727 \mathrm{~cm}^{-1}$ of the nano-GO, which would have demonstrated a reaction of the silica with the carbonyl groups forming $\mathrm{Si}-\mathrm{O}-\mathrm{C}$ bonds; hence, a confirmation of the hydrogen bonding proposed mechanism.

The effect and influence of scan rate were studied towards the electrochemical determination of $\mathrm{GA}$, using $\mathrm{CV}$ to record the voltammograms of $0.5 \times 10^{-3} \mathrm{~mol} \mathrm{~L}^{-1}$ of GA in $0.1 \mathrm{~mol} \mathrm{~L}^{-1}$ phosphate buffer of $\mathrm{pH} 2.0$. At increasing scan rates of $10,25,50,75,100,150$ and 200 $\mathrm{mVs}^{-1}$, the $I_{\mathrm{p}}$ of GA oxidation increased as the scan rate increased as seen in Fig. S1. This shows that the oxidation peak current $\left(I_{\mathrm{p}}\right)$ was linear with the scan rate $(\nu)$, indicating that the process at the electrode was an adsorption-controlled step. The linear regression equation was $I_{\mathrm{p}}(\mu \mathrm{A})=0.25 \pm 0.10, \nu\left(\mathrm{mVs}^{-1}\right)+14 \pm 1$ and $R^{2}=$ 0.9926.

It can also be observed that, with the increase in the scan rate, there was a positive shift of the peak potentials, which could suggest a kinetic limitation in the reaction $[20,27]$.

\section{Electrochemical behaviour of gallic acid at the nano- $\mathrm{GO}-\mathrm{SiO}_{2}$ nanoparticle-modified glassy carbon electrode}

The voltammetric behaviour of gallic acid was studied using cyclic voltammetry (CV). Modification of the GCE electrode by the different reagents was carried out by drop casting with an optimised volume of $5 \mu \mathrm{L}$ of nano-GO, $\mathrm{SiO}_{2}$ nanoparticles and nano-GO- $\mathrm{SiO}_{2}$ nanoparticles. The nano-GO-SiO${ }_{2}$ nanoparticles were dropped on the GCE (see Graphical abstract) and left to dry at room temperature.

The cyclic voltammograms (Fig. 3) show the determination of $1.0 \times 10^{-2} \mathrm{~mol} \mathrm{~L}^{-1}$ gallic acid using a bare GCE, $\mathrm{SiO}_{2}$ nanoparticle-modified GCE and nano-GO-SiO ${ }_{2}$ nanoparticlemodified GCE (nano-GO-SiO ${ }_{2}-\mathrm{GCE}$ ) in phosphate buffer of $\mathrm{pH} 2$ at a scan rate of $100 \mathrm{mVs}^{-1}$ in a potential range of 0.0 to $1.8 \mathrm{~V}$, at room temperature.

The modified electrodes were then used to test GA $(1 \times$ $\left.10^{-2} \mathrm{~mol} \mathrm{~L}^{-1}\right)$ and produced peak currents of $261 \pm 1 \mu \mathrm{A}$ at $0.63 \mathrm{~V}$ for the $\mathrm{SiO}_{2}$ nanoparticle $\mathrm{GCE}, 300 \pm 3 \mu \mathrm{A}$ at $0.63 \mathrm{~V}$ for the nano-GO-GCE and $411.7 \pm 0.9 \mu \mathrm{A}$ at $0.64 \mathrm{~V}$ for nano-GO-SiO${ }_{2}$ nanoparticles. In contrast, the bare (uncoated) GC electrode produced a peak current $\left(I_{\mathrm{p}}\right)$ of $241 \pm 4 \mu \mathrm{A}$ at $0.63 \mathrm{~V}$, which was lower than $I_{\mathrm{p}}$ for the modified electrodes, as can be seen in Fig. 5. Furthermore, no oxidation peak was observed within the potential range of $0.0-1.8 \mathrm{~V}$ and specifically, no peaks over the range where GA would normally occur with just the phosphate buffer $\left(0.1 \mathrm{~mol} \mathrm{~L}^{-1}\right)$ blank.

From the voltammograms shown in Fig. 5, it was deduced that, though the GCE was modified with $\mathrm{SiO}_{2}$ nanoparticles and nano-GO, the combination of both nano-compounds 
Fig. 2 FTIR images showing the spectra of a GO nanocolloids, $\mathbf{b}$ $\mathrm{SiO}_{2}$ nanoparticles and $\mathbf{c}$ a combination of the GO nanocolloids and $\mathrm{SiO}_{2}$ nanoparticles
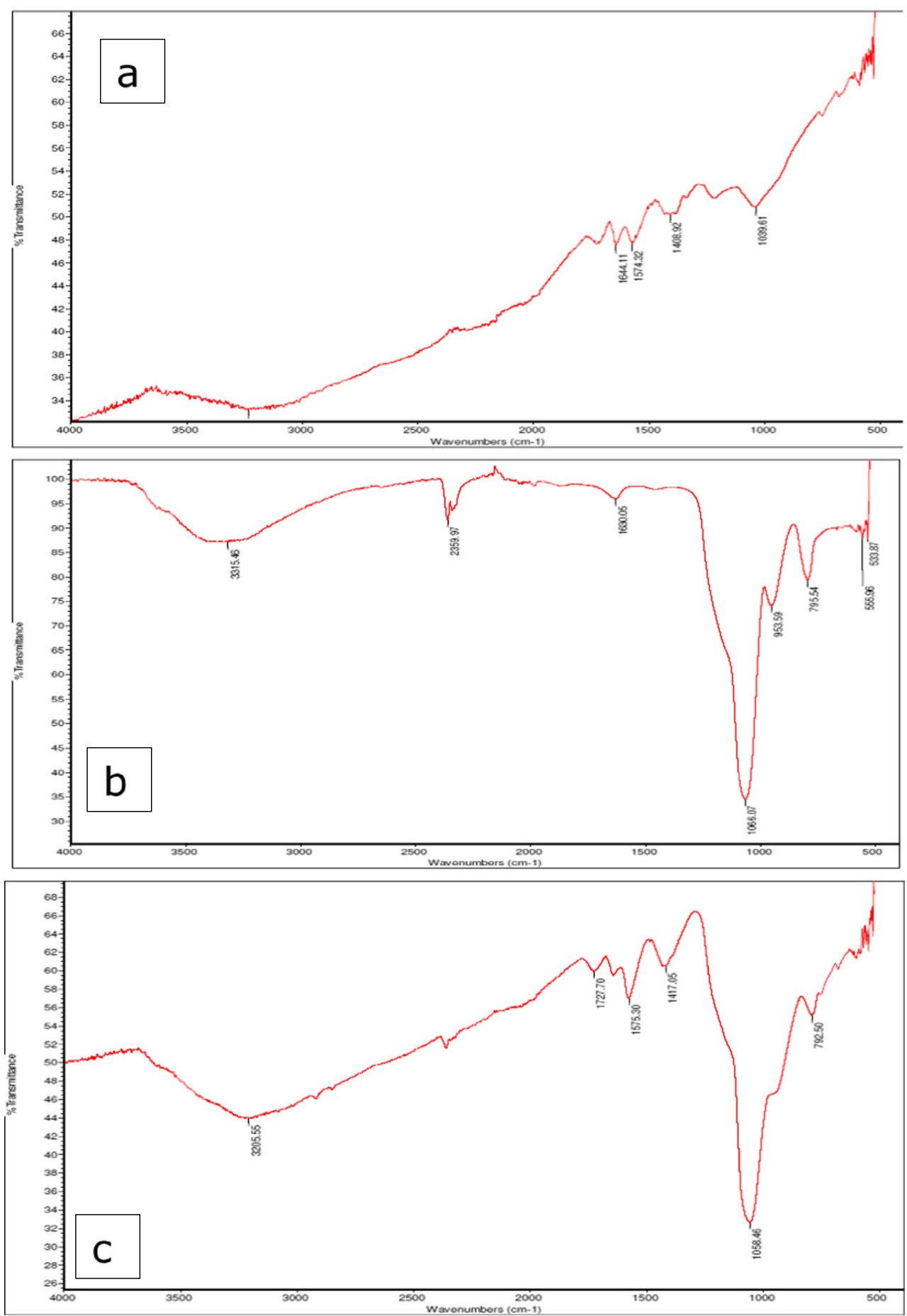

produced better peak currents compared with the individual modifiers.

Gallic acid in this determination showed two oxidation peaks during the anodic sweep between the applied potential ranges of 0.0 to $1.8 \mathrm{~V}$. The two oxidation peaks are found at peak potentials of $0.64 \mathrm{~V}$ for the first and $0.91 \mathrm{~V}$ for the second peak. These results are similar to other reports in the literature $[12,14,20]$.
These two peaks have been characterised in the literature to be the formation of a semiquinone radical (first peak) which is oxidised to a quinone in the second peak [28]. The oxidation that occurs at the first peak is because of the oxidation of the galloyl group, as can be seen in Fig. 4, which then leads to the second peak that is assumed to have been developed from the third $-\mathrm{OH}$ group in the galloyl moiety of the compound [14, 28, 29]. This 
Fig. 3 Cyclic voltammograms of $1 \times 10^{-2} \mathrm{~mol} \mathrm{~L}^{-1} \mathrm{GA}$ at nano-GO$\mathrm{SiO}_{2}$ nanoparticle-modified $\mathrm{GCE}, \mathrm{SiO}_{2}$ nanoparticlemodified GCE, nano-GOmodified GCE and a bare GCE in $0.1 \mathrm{~mol} \mathrm{~L}^{-1}$ phosphate buffer of $\mathrm{pH} 2.0$ at a scan rate of 100 $\mathrm{mVs}^{-1}(\mathrm{~S} / \mathrm{N}=3)$

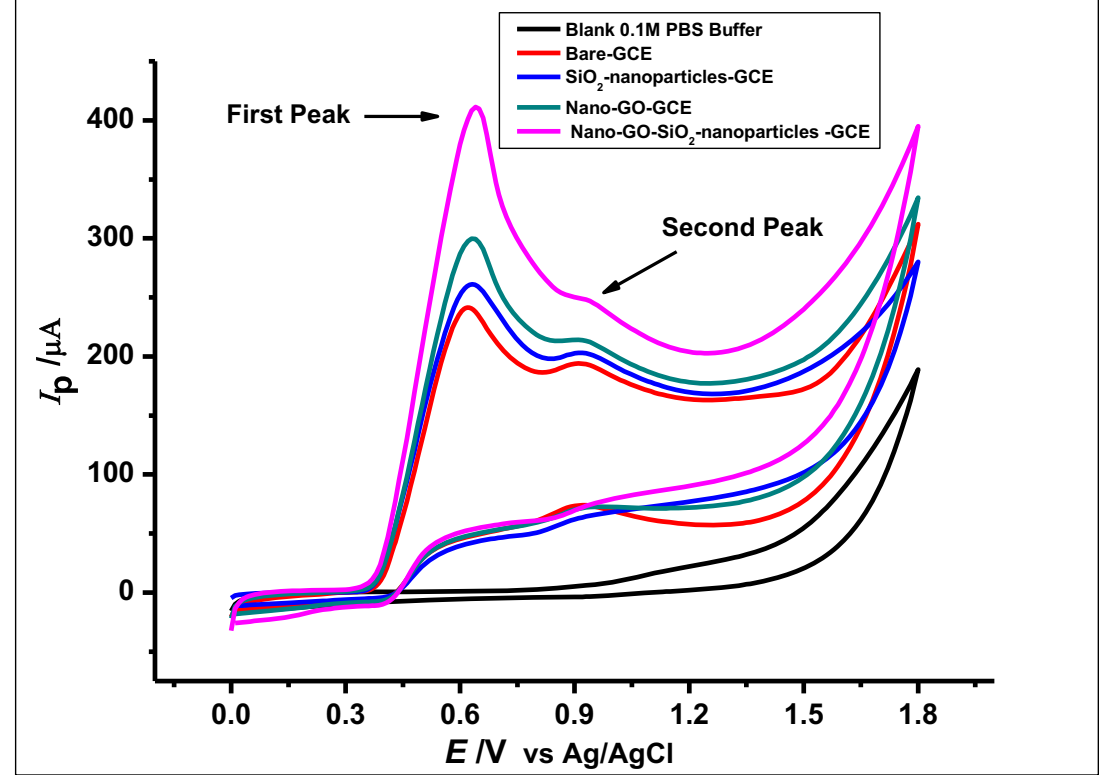

assumption is reinforced by the fact that the electrooxidation of the carboxylic group $(-\mathrm{COOH})$ occurs at $2.0 \mathrm{~V}$ and produces $\mathrm{CO}_{2}$ [12].

\section{Suggested mechanism of action}

The chemical effect of nano-GO-SiO${ }_{2}$ nanoparticles towards the oxidation of GA and the enhancement of the voltammograms can be attributed to the structural, chemical and physical properties of $\mathrm{GO}$ and $\mathrm{SiO}_{2}$. The $\mathrm{SiO}_{2}$ nanoparticles with silanol groups bind with the GO nanocolloids via hydrogen bonding as depicted in Fig. 5. The presence of hydrogen bonds on the surface of $\mathrm{SiO}_{2}$ under aqueous conditions, contributes to the electrical transport properties of graphene oxide on $\mathrm{SiO}_{2}$ surface structures. Whilst adsorbed on the surface of the graphene oxide nanocolloids, $\mathrm{SiO}_{2}$ nanoparticles also adsorbs with GA.

The mechanism proposed for this work is based on the work of S. Milonjić $[30,31]$ and colleagues, where they investigated the interaction of $\mathrm{SiO}_{2}$ and GA. They found out that $\mathrm{SiO}_{2}$ and $\mathrm{GA}$ underwent an adsorption interaction which was linked to the $\mathrm{p} K_{\mathrm{a}}$ (4.41) of GA, where the amount of adsorbed GA increases with increasing equilibrium concentration of $\mathrm{GA}$ in the solution or decreasing $\mathrm{pH}$ of the solution. Meanwhile, there was a decrease in the amount adsorbed when there was an increase in $\mathrm{pH}$ of the solution.
Fig. 4 The reaction mechanism of oxidation of gallic acid, showing the two peaks in $\mathrm{CV}$ and DPV in scheme 1<smiles>CC(C)c1cc(C(=O)O)cc(O)c1O</smiles>

Peak 2

Scheme 1<smiles>O=C(O)C1=CC(=O)C(=O)C(O)=C1</smiles> 


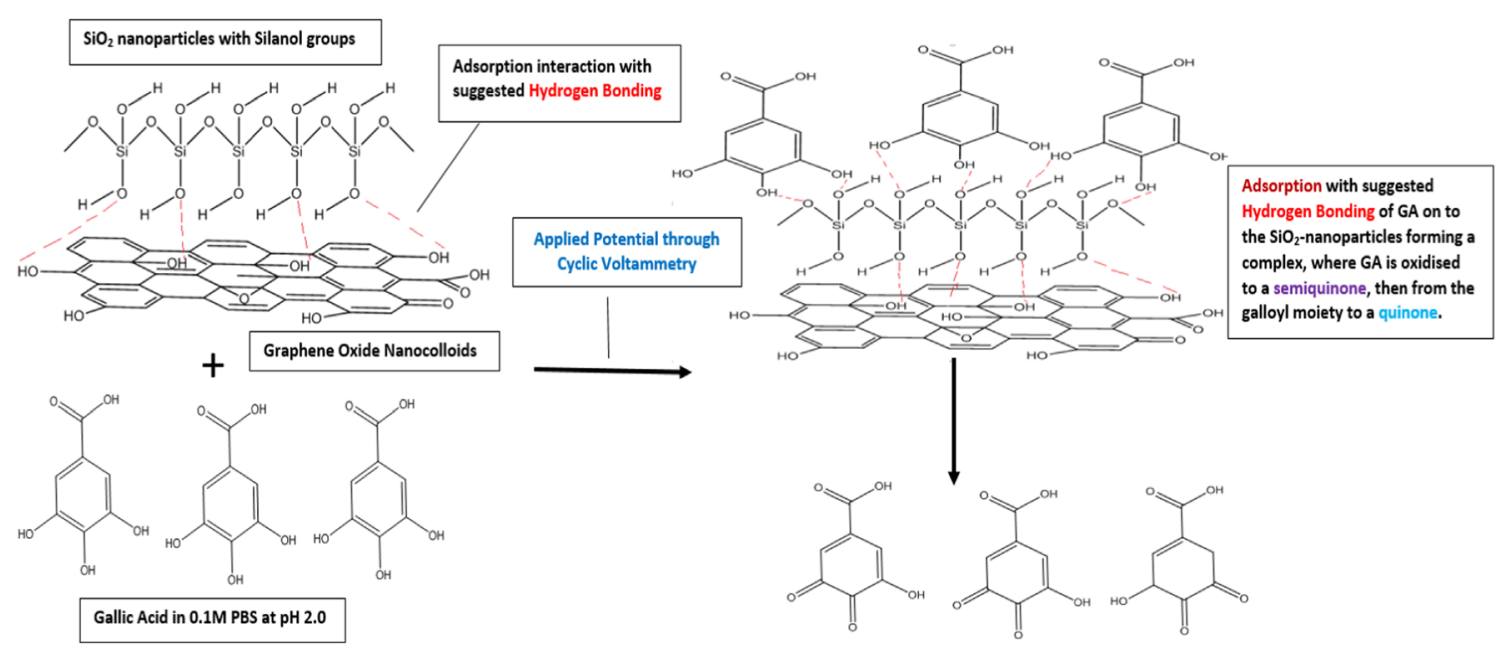

Fig. 5 Scheme showing the interaction of $\mathrm{SiO}_{2}$ nanoparticles and graphene oxide nanocolloids as they interact with gallic acid by adsorption with a suggestion of hydrogen bonding, as applied potential is sent through the modified electrode

The chemical behaviour of $\mathrm{SiO}_{2}$ and GA was then explained using the $\mathrm{p} K_{\mathrm{a}}$ of GA molecules and the surface charge of the silica powder. It should be noted that the adsorption of weak organic electrolytes like GA on the surface of amphoteric solids like silica depends amongst other things on the degree of dissociation of the electrolyte and the surface charge of the solid, which all depends on the $\mathrm{pH}$ of the aqueous solution [31]. The point of zero charge values $\left(\mathrm{pH}_{\mathrm{pzc}}\right)$, for various forms of $\mathrm{SiO}_{2}$, lie between the $\mathrm{pH}$ range of 2.5-3.6 $[30,31]$; hence, when the $\mathrm{pH}$ is below the $\mathrm{pH}_{\mathrm{pzc}}$, the surface of $\mathrm{SiO}_{2}$ becomes positively charged, whilst in a $\mathrm{pH}$ higher than the $\mathrm{pH}_{\mathrm{pzc}}$, the surface becomes negatively charged. With a $\mathrm{p} K_{\mathrm{a}}$ of a weak acid, GA at $\mathrm{pH}$ values less than 3.5 is mostly undissociated or in its stable form and dissociates when the $\mathrm{pH}$ increases.

It can therefore be interpreted that the maximum adsorption of GA to $\mathrm{SiO}_{2}$ occurs at a $\mathrm{pH}_{\mathrm{pzc}}$ where the silica surface is uncharged, and the GA molecule is un-dissociated. Hence, in a phosphate buffer solution of $\mathrm{pH} 2.0<3.5$, where the electrochemical determination takes place, GA is adsorbed on the $\mathrm{SiO}_{2}$. Meanwhile, at $\mathrm{pH}>3.5$, GA's dissociation increases, leading to an increase in the negative ion $\mathrm{C}_{6} \mathrm{H}_{2}(\mathrm{OH})_{3} \mathrm{COO}^{-}$ concentration and a negatively charged $\mathrm{SiO}_{2}$ surface. With the increase in the negative molecules and negative surface, the adsorption between $\mathrm{GA}$ and $\mathrm{SiO}_{2}$ nanoparticles decreases due to the repulsive negative-negative forces in the solution.

On the other hand, the GO nanocolloids used possess excellent electrochemical properties due to their favourable electron mobility and unique surface properties like high specific surface area that would accommodate active species like GA and facilitate electron transfer [32]. The capacity of GO to be chemically or physically functionalised, showing noncovalent $\varpi-\varpi$ ( $\varpi$-stacking), cation- $\varpi$, van der Waals or hydrogen bonding [33], formed the bases of this proposed mechanism. The $\mathrm{SiO}_{2}$ nanoparticles physically functionalise the GO nanocolloids, thus enhancing the availability of the nanosized surface area for electron transfer, whilst the adsorption of the GA to $\mathrm{SiO}_{2}$ and nanosized area provides better mass transport of the GA to the electroactive sites on the electrode surface. Meanwhile, Zhang and Choi [23] proposed an electrorheological characteristic of $\mathrm{Si}-\mathrm{GO}$ hybrid composite, hence easy transportation of electrons. Moreover, the conductive GO nanocolloids support facilitates the efficient collection and transfer of electrons to the GCE surface as described by Chen and colleagues [34].

Furthermore, an alternative and plausible explanation for the phenomenon observed in the synergistic effect of the nano- $\mathrm{GO}$ and $\mathrm{SiO}_{2}$ nanoparticles could be that of voltammetry at a three-phase junction, discussed by Oldham and Scholz et al. in their work [35-38]. They asserted that when insoluble insulating crystals like $\mathrm{SiO}_{2}$ nanoparticles adhere to an electrode, the three-phase junction (where the electrolyte solution, electrode and crystal meet) is the only feasible site for an electrochemical reaction to occur. Therefore, this implies that the redox process of gallic acid might have occurred at the three-phase junction between graphene oxide nanocolloids and $\mathrm{SiO}_{2}$ nanoparticles.

\section{Effect of concentration changes of modifier}

The effect of the changes in concentration of the nano-GO and the $\mathrm{SiO}_{2}$ nanoparticles in the modifying mixture was investigated. The following concentrations $\left(0.1 \mathrm{mg} / \mathrm{mL} \mathrm{SiO}_{2}\right.$ nanoparticles $+2 \mathrm{mg} / \mathrm{mL}$ nano-GO; $1 \mathrm{mg} / \mathrm{mL} \mathrm{SiO}_{2}$ nanoparticles + $0.2 \mathrm{mg} / \mathrm{mL} \mathrm{GO} ; 1 \mathrm{mg} / \mathrm{mL} \mathrm{SiO}_{2}$ nanoparticles $+2 \mathrm{mg} / \mathrm{mL} \mathrm{GO}$ and $5 \mathrm{mg} / \mathrm{mL} \mathrm{SiO}_{2}$ nanoparticles $+2 \mathrm{mg} / \mathrm{mL} \mathrm{GO}$ ) were used for the modification of the glassy carbon electrode and used to determine $1 \times 10^{-2} \mathrm{~mol} \mathrm{~L}^{-1} \mathrm{GA}$. The combinations studied 
Fig. 6 Voltammograms showing changes in the constitution of the nano-GO- $\mathrm{SiO}_{2}$ nanoparticles used to determine $1 \times 10^{2} \mathrm{~mol} \mathrm{~L}^{-1}$ GA in $0.1 \mathrm{~mol} \mathrm{~L}^{-1}$ phosphate buffer at $\mathrm{pH} 2.0$ using $\mathrm{CV}$ at a scan rate of $100 \mathrm{mVs}^{-1}$

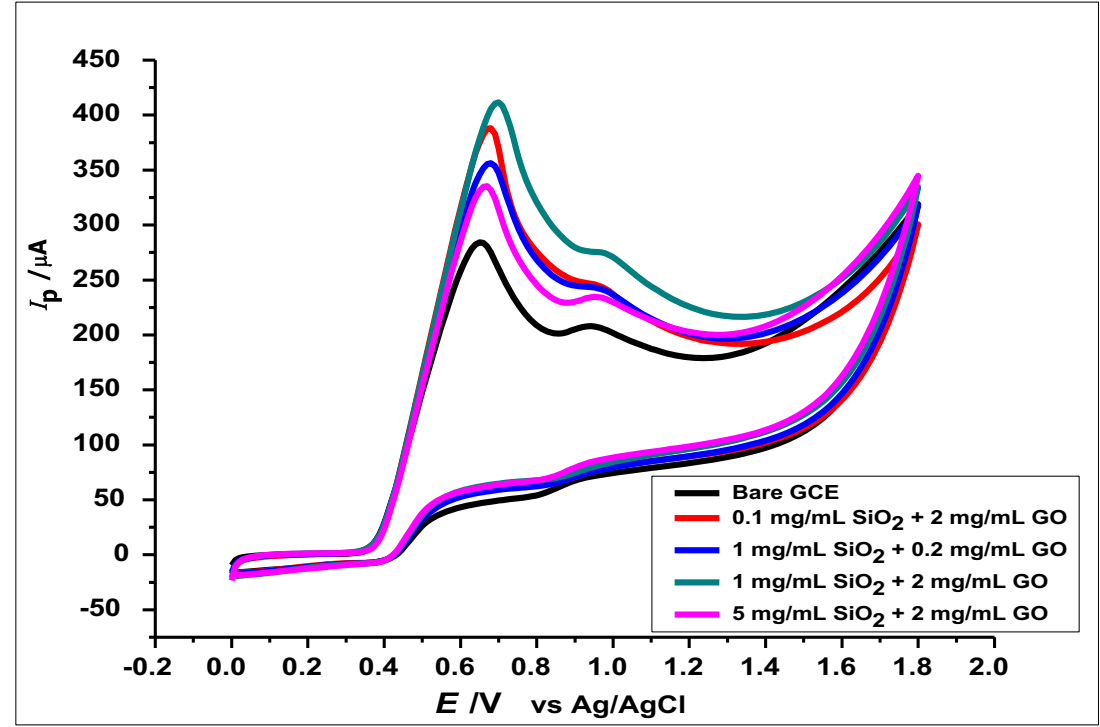

had equal amounts of nano-GO and $\mathrm{SiO}_{2}$ nanoparticles of variable concentration, sonicated for $1 \mathrm{~h}$ to enable uniform dispersion and bonding of the two compounds. From the results (Fig. 6), the combination of $1 \mathrm{mg} / \mathrm{mL} \mathrm{SiO}_{2}$ nanoparticles $+2 \mathrm{mg} / \mathrm{mL}$ GO nanocolloids showed the highest peak current $\left(I_{\mathrm{p}}\right)$ of $411.7 \mu \mathrm{A}$; hence, this combination was subsequently used for modification of the GCE.

\section{Effect of changes in the volume of modifier on GCE}

The quantity of nano-GO- $\mathrm{SiO}_{2}$ nanoparticle drop-cast on the glassy carbon electrode and the effect on the determination of $1 \times 10^{-2} \mathrm{~mol} \mathrm{~L}^{1} \mathrm{GA}$ in a $0.1 \mathrm{~mol} \mathrm{~L}^{-1}$ phosphate buffer at a $\mathrm{pH}$ of 2.0, using $\mathrm{CV}$ at a scan rate of $100 \mathrm{mVs}^{-1}$, were investigated. Volumes of 2 to $5 \mu \mathrm{L}$ were studied, and it was observed that $5 \mu \mathrm{L}$ of nano-GO- $\mathrm{SiO}_{2}$ nanoparticles gave the highest peak current $\left(I_{\mathrm{p}}\right)$ of $405.18 \mu \mathrm{A}$, as a further increase in the volume made no difference, but instead reduced the peak current, as they seem to foul the electrode surface. The volume of the mixture used for the GCE modification for further experiments was $5 \mu \mathrm{L}$.

\section{Effect of adsorption time}

The effect of the adsorption of GA to the electrode with time was demonstrated by the detection of GA $\left(1 \times 10^{-3} \mathrm{~mol} \mathrm{~L}^{-1}\right)$ in a $0.1 \mathrm{~mol} \mathrm{~L}^{-1}$ phosphate buffer of $\mathrm{pH} 2.0$ at room temperature using DPV at a scan rate of $100 \mathrm{mV} / \mathrm{s}^{-1}$.

The voltammograms in Fig. 7 demonstrated the adsorption of gallic acid onto the nano- $\mathrm{GO}-\mathrm{SiO}_{2}$ nanoparticle electrode
Fig. 7 DPV voltammograms showing the effect of adsorption time in the determination of $1 x$ $10^{-3} \mathrm{~mol} \mathrm{~L}^{-1} \mathrm{GA}$ in $0.1 \mathrm{~mol} \mathrm{~L}^{-1}$ phosphate buffer of $\mathrm{pH} 2.0$ at a scan rate of $100 \mathrm{mVs}^{-1}$ (inset) and the plots showing the same effect of adsorption time

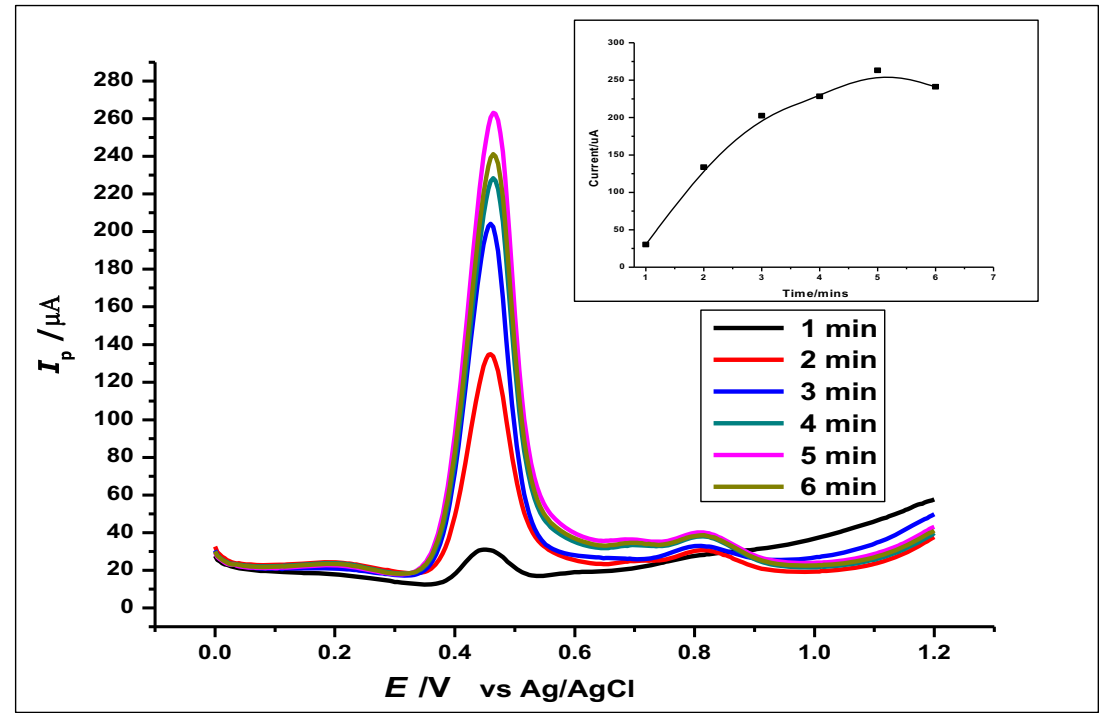


by showing a sharp increase after the first scan to an optimum by the fourth to fifth minute, reaching saturation of the GA on the electrode after 6 min. This phenomenon confirms the proposed interaction mechanism of GA and the nano-GO-SiO nanoparticles as being an adsorption reaction and is in agreement with the work of Tashkhourian [14].

\section{Effect of pH on gallic acid oxidation}

The effect of the $\mathrm{pH}$ of the gallic acid solution towards its electrochemical activity and the activity of the nano-GO$\mathrm{SiO}_{2}-\mathrm{GCE}$ were investigated. The electrochemical response of gallic acid $\left(1 \times 10^{-4} \mathrm{~mol} \mathrm{~L}^{-1}\right)$ was studied with $\mathrm{pH}$ ranging from 2.0 to 8.0 using cyclic voltammetry at a scan rate of 100 $\mathrm{mVs}^{-1}$, in phosphate buffer $\left(0.1 \mathrm{~mol} \mathrm{~L}^{-1}\right)$. The oxidation peak and the peak potential $\left(E_{\mathrm{p}}\right)$ shown have clearly been influenced by the $\mathrm{pH}$, as can be seen in Fig. 8 . From the voltammograms, a $\mathrm{pH}$ value of 2.0 showed a well-shaped oxidation peak, with the highest peak current $\left(I_{\mathrm{p}}\right)$ of $33.72 \mu \mathrm{A}$.

On the other hand, as the $\mathrm{pH}$ increases, there was a reduction in the peak current (Fig. 8a). For example, at $\mathrm{pH} 8$, the lowest peak current of $23.70 \mu \mathrm{A}$ was observed. There was also a negative shift of the oxidation peak potential from $0.56 \mathrm{~V}$ downwards to $0.31 \mathrm{~V}$, as can be seen in Fig. 8 a, with a gradual broadening of the oxidation peak/peak area with the increase in $\mathrm{pH}$.

The relationship between the $\mathrm{pH}$ and the peak potential $\left(E_{\mathrm{p}}\right)$ shows a good linear relationship as can be seen in Fig. $8 \mathrm{~b}$ in the $\mathrm{pH}$ range of 2.0 to 8.0 , with a linear regression equation of $E_{\mathrm{pa}} V=0.70 \pm 0.01-0.05 \pm 0.03 \mathrm{pH}$, with $R^{2}=$ 0.9960 . The slope of the regression line, $54 \mathrm{mV} / \mathrm{pH}$, is comparable with the Nernstian value of $59 \mathrm{mV} / \mathrm{pH}$ at $25^{\circ} \mathrm{C}$, for equal number of proton and electron transfer reactions. The $\mathrm{pH}$ and peak potential relationship is thus consistent with a
Fig. 8 a Cyclic voltammograms showing the effect of $\mathrm{pH}$ on the electrochemical behaviour of $1 \times$ $10^{-4} \mathrm{~mol} \mathrm{~L}^{-1}$ gallic acid (inset). Plot of the peak current $\left(I_{\mathrm{p}}\right)$ against different $\mathrm{pH}$ values showing the effect of $\mathrm{pH}$ on the electrochemical behaviour of $1 \times$ $10^{-4} \mathrm{~mol} \mathrm{~L}^{-1}$ gallic acid using bare glassy carbon electrode at a scan rate of $100 \mathrm{mVs}^{-1}$. b Plot of the peak potential $E_{\mathrm{p}}$ on detection of $1 \times 10^{-4} \mathrm{~mol} \mathrm{~L}^{-1}$ gallic acid using nano- $\mathrm{GO}-\mathrm{SiO}_{2}-\mathrm{GCE}$ as a function of $\mathrm{pH}$, measured at a scan rate of $100 \mathrm{mVs}^{-1}$
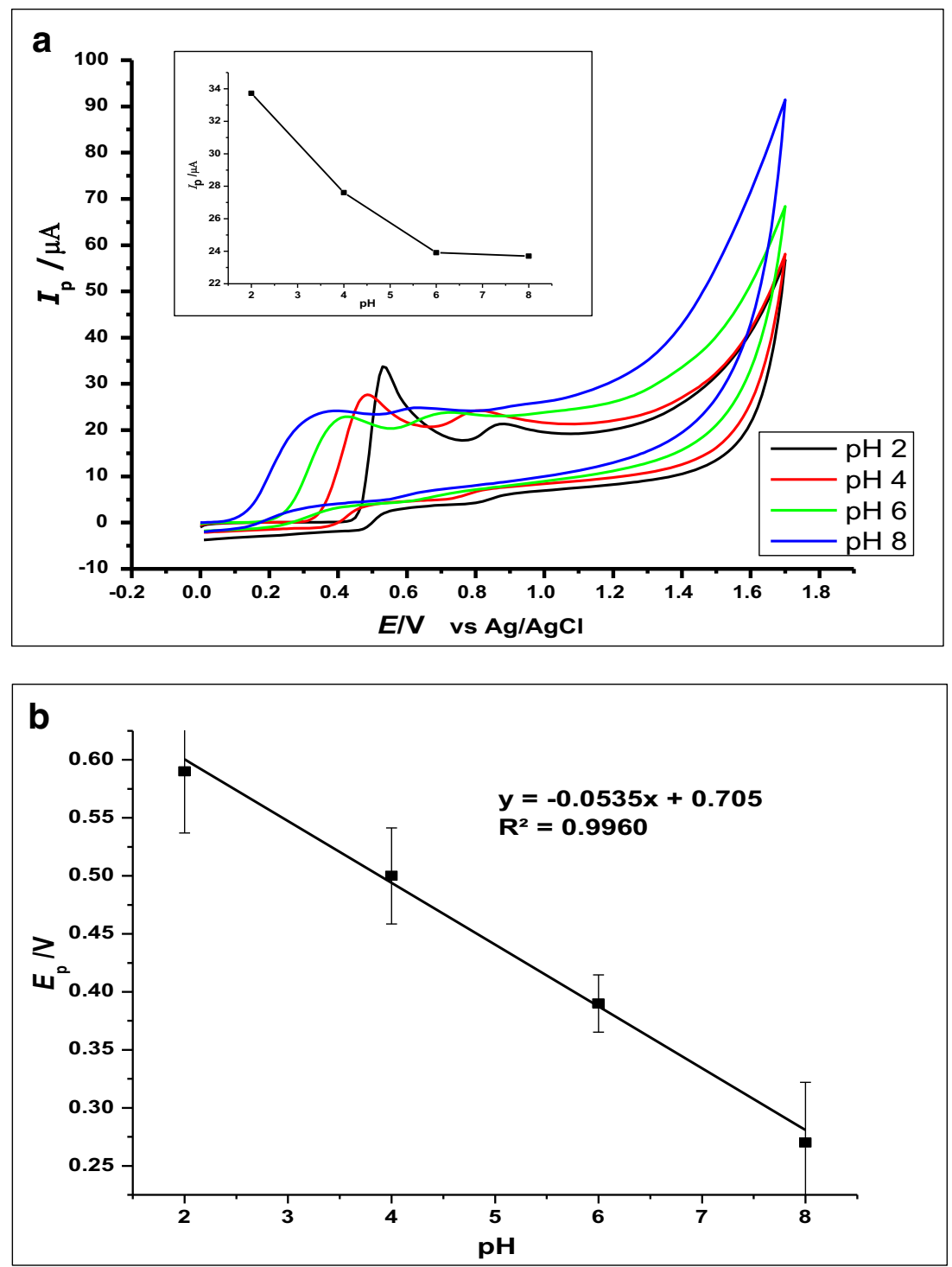
two-proton/two-electron reaction, which is consistent with other literature data $[14,20]$. Based on the results, the $\mathrm{pH}$ condition selected as the most appropriate for the oxidation of gallic acid in this experiment was $\mathrm{pH} 2.0$.

This may be attributed to the fact that GA, with a $K_{\mathrm{a}}$ of 4.4 being a weak organic acid, is most stable or is in its nondissociated state at $\mathrm{pH}$ 2.0. This $\mathrm{pH}$ was the most appropriate for the adsorption of GA on to $\mathrm{SiO}_{2}$.

\section{Limit of detection for the electrochemical oxidation of GA}

Differential pulse voltammetry was used for the investigation of different concentrations of GA, to determine the limit of detection (LOD) at a scan rate of $100 \mathrm{mVs}^{-1}$ and pulse amplitude of $80 \mathrm{mV}$. With the increase in concentration studied in the range of $6.25 \times 10^{-6}$ to $1.0 \times 10^{-3} \mathrm{~mol}$ $\mathrm{L}^{-1}$, there was a correlated increase in the peak current, whilst using the nano-GO-SiO${ }_{2}$ nanoparticle-modified electrode. The measurements produced voltammograms (Fig. 9) in which the peak current increased proportionally with increasing gallic acid concentration. Using DPV in this measurement produced two oxidation peaks at peak potentials of $0.45 \mathrm{~V}$ and $0.8 \mathrm{~V}$ as different concentrations of GA were being determined.

Using the first main GA oxidation peak, the analytical calibration graph as seen in Fig. 9 (inset) showed a linear relationship between the peak current and the increase in gallic acid concentration, producing a linear regression equation, where $I_{\mathrm{P}}(\mu \mathrm{A})=221 \pm 5.5, C\left(\mathrm{mmol} \mathrm{L}^{-1}\right)+9.43 \pm 2$ and $R^{2}$ $=0.9956$ within a range of $6.25 \times 10^{-6}$ to $1.0 \times 10^{-3} \mathrm{~mol} \mathrm{~L}^{-1}$. The limit of detection (LOD), defined as $\left(3 \times \operatorname{Std}_{\text {Blank }}\right) / m$, where $\operatorname{Std}_{\text {Blank }}$ is the standard deviation of the blank and $m$ is the slope, was found to be $2.09 \times 10^{-6} \mathrm{~mol} \mathrm{~L}^{-1}$.

The proposed method is comparable with other methods based on the maximum permitted antioxidant levels in food within EU and North American guidelines, which ranges from 20 to $1000 \mathrm{ppm}$ (20 to $1000 \mathrm{mg} \mathrm{L}^{-1}$ ) [39]. Hence, for GA, the permitted range would be $1.2 \times 10^{-1} \mathrm{~mol} \mathrm{~L}^{-1}$ to $5.9 \mathrm{~mol} \mathrm{~L}^{-1}$. Thus, with an LOD of $2.09 \times 10^{-6} \mathrm{~mol} \mathrm{~L}^{-1}$ which is far below these standard permitted levels, the electrode is comparable with others, as can be seen in Table 1 .

\section{Reproducibility and repeatability of the method}

The reproducibility of the nano-GO- $\mathrm{SiO}_{2}$-modified glassy carbon electrode was investigated, by using the modified electrode to determine the oxidation peak current produced by $1.0 \times 10^{-3} \mathrm{~mol} \mathrm{~L}^{-1} \mathrm{GA}$. The oxidation peak currents produced by eight replicates of $1.0 \times 10^{-3} \mathrm{~mol} \mathrm{~L}^{-1} \mathrm{GA}$ independently measured with eight different electrodes, with a relative standard deviation of $3.8 \%$ indicated a good reproducibility.

Meanwhile, the repeatability of the method was investigated by using a nano-GO-SiO ${ }_{2}$-modified glassy carbon electrode, for eight repetitive determination of $1.0 \times 10^{-3} \mathrm{~mol}$ $\mathrm{L}^{-1}$ gallic acid. The relative standard deviation of the oxidation peak current was found to be $2.92 \%$, which shows good repeatability of the method.

\section{Stability of electrode}

The stability of the nano-GO-SiO${ }_{2}$ nanoparticle-modified glassy carbon electrode was also investigated. The electrode
Fig. 9 Differential pulse voltammograms of various concentration of GA at nano-GO$\mathrm{SiO}_{2}$ nanoparticles in $0.1 \mathrm{~mol} \mathrm{~L}^{-1}$ phosphate buffer at $\mathrm{pH} 2.0$ at a scan rate of $100 \mathrm{mVs}^{-1}$ with voltammograms $(\mathrm{a}-\mathrm{j})$ that corresponds to the following concentrations: (a) 0.0, (b) $0.00625 \mathrm{mmol} \mathrm{L}^{-1}$, (c) $0.0125 \mathrm{mmol} \mathrm{L}^{-1}$, (d) $0.025 \mathrm{mmol} \mathrm{L}^{-1}$, (e) $0.05 \mathrm{mmol}$ $\mathrm{L}^{-1}$, (f) $0.075 \mathrm{mmol} \mathrm{L}^{-1}$, (g) $0.1 \mathrm{mmol} \mathrm{L}^{-1}$, (h) $0.25 \mathrm{mmol} \mathrm{L}^{-1}$, (i) $0.5 \mathrm{mmol} \mathrm{L}^{-1}$, (j) $0.75 \mathrm{mmol}$ $\mathrm{L}^{-1}$, (k) $1 \mathrm{mmol} \mathrm{L}^{-1}$. (Inset) The calibration curve for the determination of GA

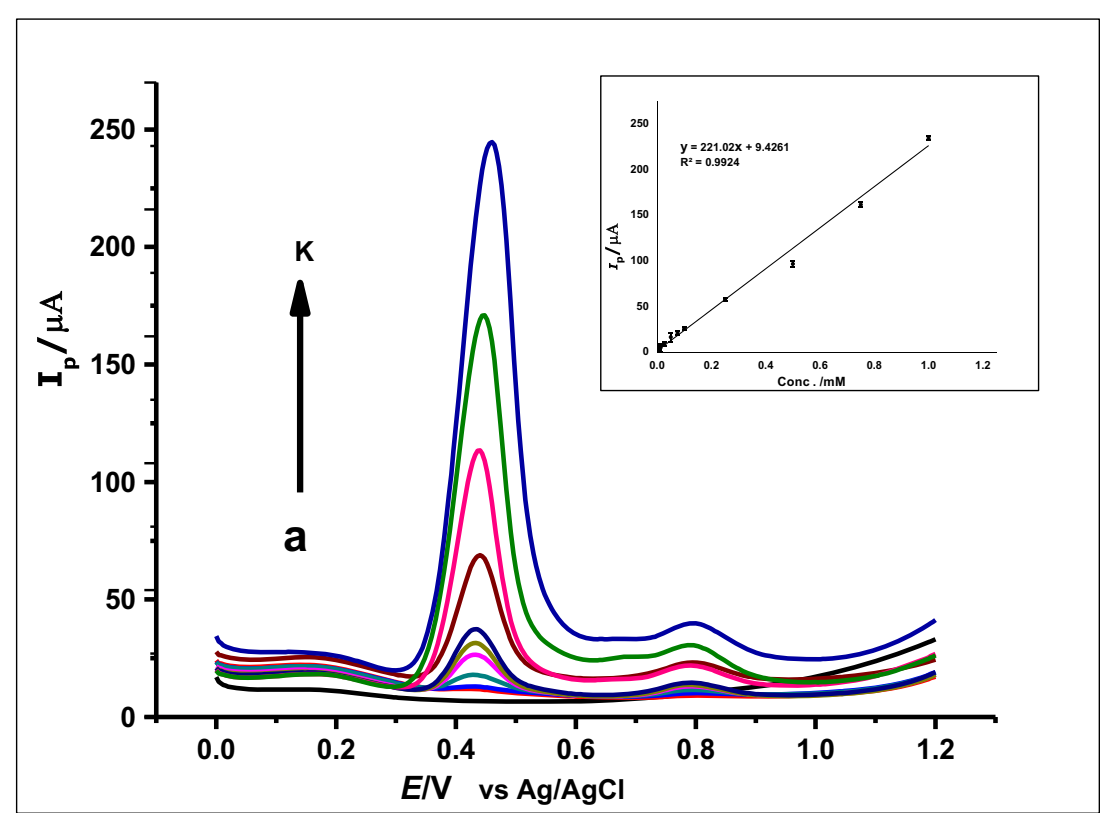


was kept for 30 days and was used for the determination of 1.0 $\times 10^{-3} \mathrm{~mol} \mathrm{~L}^{-1}$ gallic acid and the oxidation peak currents produced from the readings of the first day and that of the 30th day showed an RSD of $6.58 \%$, depicting a relatively good stability.

\section{Selectivity of the method}

The selectivity of the modified glassy carbon electrode was tested, by the simultaneous detection of GA and uric acid (UA) in a $0.1 \mathrm{~mol} \mathrm{~L}^{-1}$ phosphate buffer solution at a $\mathrm{pH}$ of 2.0 using $\mathrm{CV}$ at a scan rate of $100 \mathrm{mVs}^{-1}$, at room temperature. This was done by the addition of $0.48 \mathrm{mmol} \mathrm{L}^{-1}$ of GA into a $10-\mathrm{mL}$ cell of $0.36 \mathrm{mmol} \mathrm{L}^{-1}$ uric acid and voltammograms recorded, as seen in Fig. 10 a. A concentration of $0.48 \mathrm{mmol} \mathrm{L}^{-1}$ of GA was used, because it was at this concentration that a significant distinction of the voltammograms of GA and UA was observed. GA and UA showed distinct peaks at approximately $0.51 \mathrm{~V}$ and $0.64 \mathrm{~V}$, respectively, with the smaller second GA oxidation at a peak potential of $0.88 \mathrm{~V}$. Meanwhile, the voltammograms of UA on its own without GA showed an oxidation peak at $0.64 \mathrm{~V}$ and that of GA on its own show oxidation peaks at $0.5 \mathrm{~V}$ for the first peak and at $0.88 \mathrm{~V}$ for the second smaller peak (Fig. 10b).

To confirm the selectivity of the electrode, the UA concentration was kept constant at $0.36 \mathrm{mmol} \mathrm{L}^{-1}$ in a $10-\mathrm{mL}$ voltammetric cell and then aliquots of $100 \mu \mathrm{L}$ of $10 \mathrm{mmol} \mathrm{L}^{-1}$ GA were intermittently added and then vigorously stirred for $2 \mathrm{~min}$. Voltammograms were then recorded, as can be seen in Fig. 10 b. In this case, the nanoGO-SiO ${ }_{2}$ nanoparticle-modified GCE produced the voltammograms as can be seen in Fig. 10 b, where increasing the concentration of GA showed a proportional increase in the peak current. Hence, Fig. 10 b (inset) shows a linear relationship between the peak current and the increase in gallic acid concentration, producing a linear regression equation where $I_{P}(\mu \mathrm{A})=13.0 \pm 0.6, C(\mathrm{mmol}$ $\left.\mathrm{L}^{-1}\right)+1.41 \pm 0.20$ and $R^{2}=0.9915$ within a range of 0.1 to $0.48 \mathrm{mmol} \mathrm{L}^{-1}$.

\section{Interferences}

The interference of various species in the determination of $1 \times 10^{-3} \mathrm{~mol} \mathrm{~L}^{-1}$ gallic acid was also investigated (Table 2). This was carried out by adding different amounts of foreign ions to a known quantity of the analyte as it was being determined. The foreign species that were used in this case for the investigation of interference were $\mathrm{K}^{+}, \mathrm{Ca}^{2+}, \mathrm{Fe}^{3+}$ and $\mathrm{Na}^{+}$, then ascorbic acid, caffeine, caffeic acid and quercetin, respectively. The selection of some of the cations was based on reports of their complexation with GA in the literature $[40,41]$ and the 
Fig. 10 a Cyclic voltammograms showing $0.36 \mathrm{mmol} \mathrm{L}^{-1}$ uric acid concentration, $0.48 \mathrm{mmol} \mathrm{L}^{-1} \mathrm{GA}$ and a mixture of the two concentrations of GA and UA in a $0.1 \mathrm{~mol} \mathrm{~L}^{-1}$ phosphate buffer solution at a $\mathrm{pH} 2.0$ at scan rate $100 \mathrm{mVs}^{-1}$. b Cyclic voltammograms showing the constant 0.36 mmol L UA concentration and increasing GA concentration from 0.1 to $0.48 \mathrm{mmol} \mathrm{L}^{-1}$ in $0.1 \mathrm{~mol} \mathrm{~L}^{-1}$ phosphate buffer at $\mathrm{pH} 2.0$ at a scan rate of $100 \mathrm{mVs}^{-1}$. (Inset) A graph showing the increasing concentration of GA against the increasing peak current in a constant UA concentration of 3.6 $\times 10^{-4} \mathrm{~mol} \mathrm{~L}^{-1}$
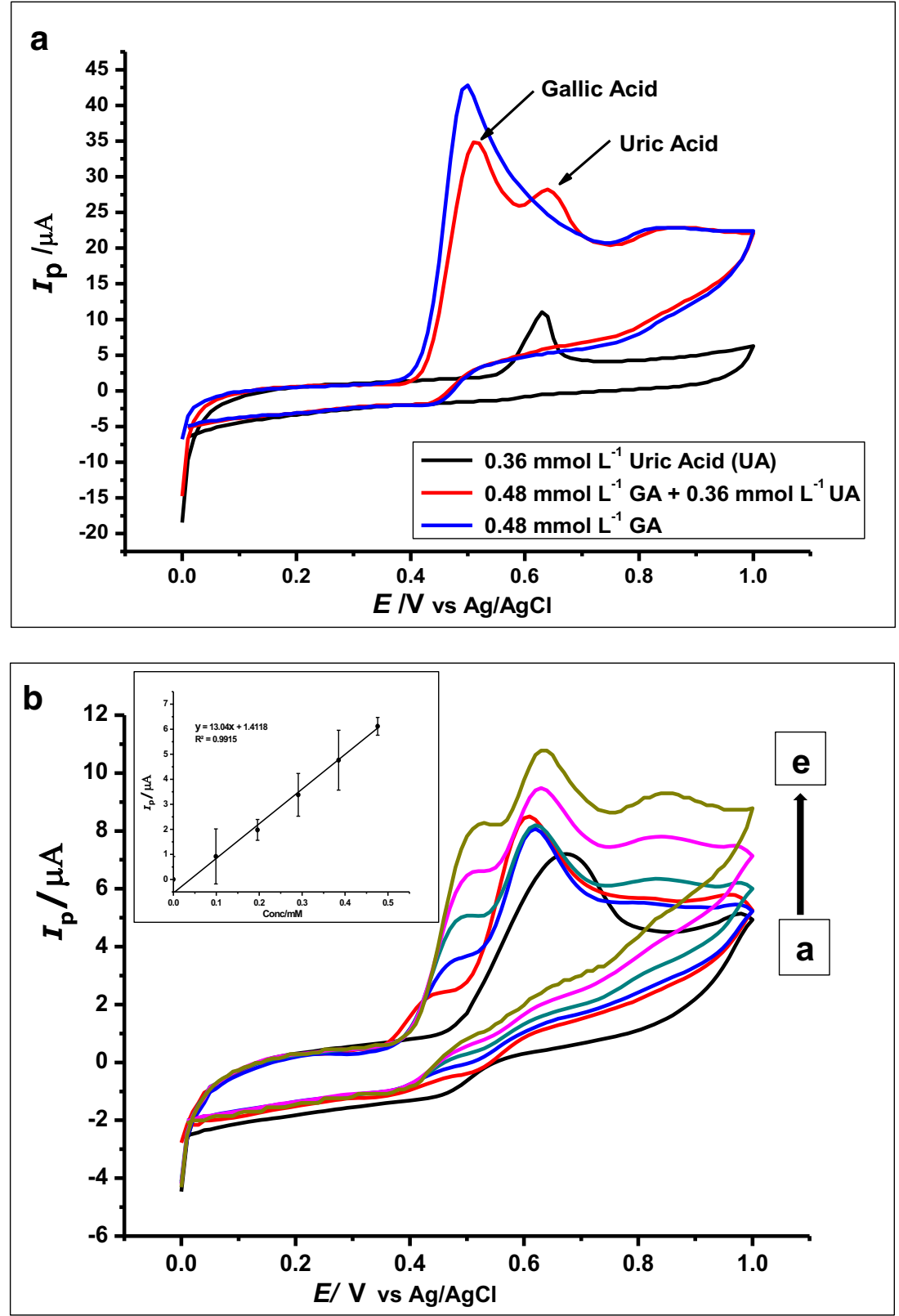

possibility of these compounds interfering with the electrochemical determination of GA. The tolerable limits of these ions for interference was defined as the highest amounts of foreign ions that would produce an error of not more that $5 \%$ in the determination of the analyte, which in this case is gallic acid. With relative standard error values of less than $5 \%$, these ions did not interfere with the determination of gallic acid at the first GA oxidation peak, as can be seen in the results shown in Fig. 11. However, there were some minor changes in the second GA oxidation peak, which is not normally the peak used for electrochemical determination of GA.
Table 2 Effects of various substances on the determination of $1 \times 10^{-3}$ mol L ${ }^{-1}$ gallic acid

\begin{tabular}{lll}
\hline Interfering species & $\begin{array}{l}\text { Amount in } \\
\text { solution }\left(\mathrm{mol} \mathrm{L}^{-1}\right)\end{array}$ & $\begin{array}{l}\text { Relative standard } \\
\text { deviation }(\%)\end{array}$ \\
\hline $\mathrm{Ca}^{2+}$ & $1 \times 10^{-1}$ & \pm 3.70 \\
$\mathrm{Na}^{+}$ & $1 \times 10^{-1}$ & \pm 1.29 \\
$\mathrm{Fe}^{3+}$ & $1 \times 10^{-1}$ & \pm 1.93 \\
$\mathrm{Cl}^{-}$ & $1 \times 10^{-1}$ & \pm 2.01 \\
$\mathrm{CO}_{3}^{2-}$ & $1 \times 10^{-1}$ & \pm 1.45 \\
$\mathrm{Ascorbic}^{2-}$ acid & $1 \times 10^{-3}$ & \pm 0.15 \\
Caffeic acid & $1 \times 10^{-3}$ & \pm 2.80 \\
Caffeine & $1 \times 10^{-3}$ & \pm 3.89 \\
Quercetin & $1 \times 10^{-3}$ & \pm 4.64 \\
\hline
\end{tabular}


Fig. 11 DPV voltammograms of $1 \times 10^{-3} \mathrm{~mol} \mathrm{~L}^{-1}$ gallic acid with different concentrations of some known interfering compounds in $0.1 \mathrm{~mol} \mathrm{~L}^{-1}$ phosphate buffer at pH 2.0 and a scan rate of 100 $\mathrm{mVs}^{-1}$

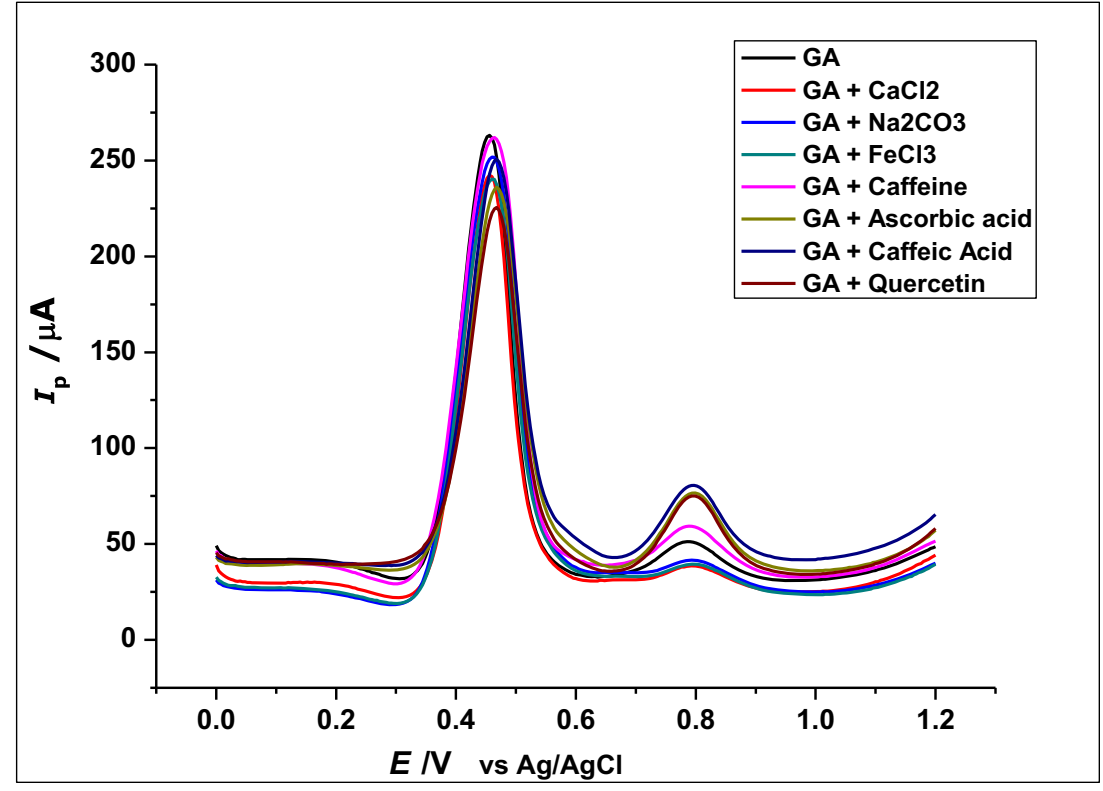

\section{Analytical application of the method}

This analytical method with the nano-GO-SiO${ }_{2}$ nanoparticlemodified electrode was used for the determination of GA in red wine, white wine and orange juice. The real samples (i.e. red wine, white wine and orange juice) were used based on previous work from other group showing the presence of GA in those types of samples [14]. However, in red wine, white wine and orange juice GA were not detected. This may be due to the origin and nature of the samples. Hence, spiking methodology was applied to all samples to clearly demonstrate the potential of our proposed sensor as shown in Table 3. The experiments were done by using $10 \mathrm{~mL}$ of the real samples as blanks and then the standard addition of known concentrations of aliquots of gallic acid within a concentration range of $9.0 \times 10^{-4}$ to $4.7 \times 10^{-3} \mathrm{~mol} \mathrm{~L}^{-1}$ was added to the cells containing the real samples and the voltammograms recorded and the results calculated as can be seen in Table 3 .

\section{Conclusion}

In this paper, for the first time, graphene oxide nanocolloids mixed with $\mathrm{SiO}_{2}$ nanoparticles synthesised by the sol-gel method were drop-cast on a glassy carbon electrode. This electrode was then used for the electrochemical determination of gallic acid in a $0.1 \mathrm{~mol} \mathrm{~L}^{-1}$ phosphate buffer at $\mathrm{pH} 2.0$. Cyclic and differential pulse voltammetry were used as the electrochemical techniques and it was found that graphene nanocolloids mixed with $\mathrm{SiO}_{2}$ nanoparticles showed an electrochemical effect towards the oxidative determination of gallic acid, within a concentration range of $6.2 \times 10^{-6}$ to $1.0 \times$ $10^{-3} \mathrm{~mol} \mathrm{~L}^{-1}$.

The modified electrode demonstrated selectivity towards the determination of gallic acid and uric acid, which is a marked advantage over other electrodes in the literature.

The electrode was found to be a simple, sensitive, fast and cost-effective method for the determination of gallic acid; it
Table 3 Results of the analysis of GA in spiked red wine, white wine and orange juice and the validation HPLC result of red wine

\begin{tabular}{lllll}
\hline Samples & Added $\left(\mathrm{mol} \mathrm{L}^{-1}\right)$ & Found $\left(\mathrm{mol} \mathrm{L}^{-1}\right)$ & Relative error & Recovery (\%) \\
\hline Red Wine & 0.0 & Undetected & - & - \\
& $1.66 \times 10^{-4}$ & $1.689 \times 10^{-4}$ & \pm 2.32 & 102.3 \\
& $2.30 \times 10^{-4}$ & $2.47 \times 10^{-4}$ & \pm 7.39 & 107.4 \\
White Wine & 0.0 & Undetected & - & - \\
& $1.66 \times 10^{-4}$ & $1.583 \times 10^{-4}$ & \pm 4.64 & 95.4 \\
& $2.30 \times 10^{-4}$ & $2.42 \times 10^{-4}$ & \pm 5.65 & 105.7 \\
Orange Juice & 0.0 & Undetected & - & - \\
& $1.70 \times 10^{-4}$ & $1.66 \times 10^{-4}$ & \pm 2.36 & 97.6 \\
& $2.30 \times 10^{-4}$ & $2.379 \times 10^{-4}$ & \pm 3.44 & 103.4 \\
\hline
\end{tabular}


showed very good reproducibility, repeatability and a relatively good long-term stability.

The electrochemical sensor was successfully applied as a sensitive electrochemical method for the determination of gallic acid in red wine, white wine and orange juice within the concentration range of $9.0 \times 10^{-4}$ to $4.7 \times 10^{-3} \mathrm{~mol} \mathrm{~L}^{-1}$. The results showed the present method to be comparable with some of the other methods in the literature, as it detects far below the maximum permitted gallic acid levels in food within the EU and North America.

Acknowledgement The authors would want to acknowledge the laboratory staff of the research and teaching labs of the School of Pharmacy and Life Sciences of the Robert Gordon University, for their support during this work.

Open Access This article is distributed under the terms of the Creative Commons Attribution 4.0 International License (http:// creativecommons.org/licenses/by/4.0/), which permits unrestricted use, distribution, and reproduction in any medium, provided you give appropriate credit to the original author(s) and the source, provide a link to the Creative Commons license, and indicate if changes were made.

\section{References}

1. Yilmaz ÜT, Kekillioglu A, Mert R (2013) Determination of Gallic acid by differential pulse polarography: application to fruit juices. $\mathrm{J}$ Anal Chem 68(12):1064-1069

2. Becerra-Herrera M, Lazzoi MR, Sayago A, Beltrán R, del Sole R, Vasapollo G (2015) Extraction and determination of phenolic compounds in the berries of Sorbus Americana Marsh and Lonicera oblongifolia (Goldie) hook. Food Anal Methods 8(10):2554-2559

3. Jeng Dong H, Shao Hsuan K, Ting Tsz O et al (2011) Gallic acid induces $\mathrm{G} 2 / \mathrm{M}$ phase arrest of breast cancer cell MCF-7 through stabilization of p27Kip1 attributed to disruption of p27 Kip1/Skp2 complex. J Agric Food Chem 59:1996-2003

4. Pinchuk I, Shoval H, Dotan Y, Lichtenberg D (2012) Evaluation of antioxidants: scope, limitations and relevance of assays. Chem Phys Lipids 165(6):638-647

5. Pisoschi AM, Cimpeanu C, Predoi G (2015) Electrochemical methods for total antioxidant capacity and its main contributors determination: a review. Open Chem 13:824-856

6. Prieto-Simón B, Cortina M, Campàs M, Calas-Blanchard C (2008) Electrochemical biosensors as a tool for antioxidant capacity assessment. Sensors Actuators, B Chem 129(1):459-466

7. Tasioula-Margari M, Tsabolatidou E (2015) Extraction, separation, and identification of phenolic compounds in virgin olive oil by HPLC-DAD and HPLC-MS. Antioxidants 4(3):548-562

8. Zheng X, Hu Y, Anggreani E, Lu X (2017) Determination of total phenolic content and antioxidant capacity of blueberries using Fourier transformed infrared (FT-IR) spectroscopy and Raman spectroscopy. J Food Meas Charact 11(4):1909-1918

9. Saraji M, Mousavi F (2010) Use of hollow fibre-based liquidliquid-liquid microextraction and high-performance liquid chromatography-diode array detection for the determination of phenolic acids in fruit juices. Food Chem 123(4):1310-1317

10. Porgali E, Büyüktuncel E (2012) Determination of phenolic composition and antioxidant capacity of native red wines by high performance liquid chromatography and spectrophotometric methods. Food Res Int 45(1):145-154
11. Parveen S, Aslam MS, Hu L, Xu G (2013) Electrogenerated chemiluminescence protocols and applications. Springer US

12. Ghaani M, Nasirizadeh N, Yasini Ardakani SA, Mehrjardi FZ, Scampicchio M, Farris S (2016) Development of an electrochemical nanosensor for the determination of gallic acid in food. Anal Methods 8(5):1103-1110

13. Kariuki J, Ervin E, Olafson C (2015) Development of a novel, lowcost, disposable wooden pencil graphite electrode for use in the determination of antioxidants and other biological compounds. Sensors (Switzerland) 15(8):18887-18900

14. Tashkhourian J, Nami-Ana SF (2015) A sensitive electrochemical sensor for determination of gallic acid based on $\mathrm{SiO} 2$ nanoparticle modified carbon paste electrode. Mater Sci Eng C 52:103-110

15. Abdel-Hamid R, Newair EF (2011) Electrochemical behavior of antioxidants: I. Mechanistic study on electrochemical oxidation of gallic acid in aqueous solutions at glassy-carbon electrode. J Electroanal Chem 657(1-2):107-112

16. Devadas B, Chen SM (2015) Controlled electrochemical synthesis of yttrium (III) hexacyanoferrate micro flowers and their composite with multiwalled carbon nanotubes, and its application for sensing catechin in tea samples. J Solid State Electrochem 19(4):1103-1112

17. Han R, Cui L, Ai S, Yin H, Liu X, Qiu Y (2012) Amperometric biosensor based on tyrosinase immobilized in hydrotalcite-like compounds film for the determination of polyphenols. J Solid State Electrochem 16(2):449-456

18. Xu M, Cui L, Han R, Ai S (2012) Amperometric biosensor based on hemoglobin immobilized on $\mathrm{Cu} 2 \mathrm{~S}$ nanorods/nafion nanocomposite film for the determination of polyphenol. J Solid State Electrochem 16(7):2547-2554

19. Lukeš V, Darvasiová D, Furdíková K, Hubertová I, Rapta P (2015) Solvent effect on the anodic oxidation of tannic acids: EPR/UV-Vis spectroelectrochemical and DFT theoretical study. J Solid State Electrochem 19(9):2533-2544

20. Tashkhourian J, Ana SFN, Hashemnia S, Hormozi-Nezhad MR (2013) Construction of a modified carbon paste electrode based on $\mathrm{TiO} 2$ nanoparticles for the determination of gallic acid. J Solid State Electrochem 17(1):157-165

21. Venkatathri N (2007) Preparation of silica nanoparticle through coating with octyldecyltrimethoxy silane. Indian J Chem - Sect A Inorganic, Phys Theor Anal Chem 46:1955-1958

22. Wang S, Wang Y, Min Q et al (2016) Simultaneous electrochemical determination of dopamine and serotonin in rat cerebrospinal fluid using screen-printed electrode modified with MWNTs-SiO 2-chitosan composites. Biosens Bioelectron 11:2360-2376

23. Zhang WL, Choi HJ (2012) Silica-graphene oxide hybrid composite particles and their electroresponsive characteristics. Langmuir 28(17):7055-7062

24. Szabó T, Berkesi O, Forgó P, Josepovits K, Sanakis Y, Petridis D, Dékány I (2006) Evolution of surface functional groups in a series of progressively oxidized graphite oxides evolution of surface functional groups in a series of progressively oxidized graphite oxides. Chem Mater 18(11):2740-2749

25. Musić S, Filipović-Vinceković N, Sekovanić L (2011) Precipitation of amorphous $\mathrm{SiO} 2$ particles and their properties. Brazilian J Chem Eng 28(1):89-94

26. Lee KG, Wi R, Imran M, Park TJ, Lee J, Lee SY, Kim DH (2010) Functionalization effects of single-walled carbon nanotubes as templates for the synthesis of silica nanorods and study of growing mechanism of silica. ACS Nano 4(7):3933-3942

27. Raoof JB, Ojani R, Kolbadinezhad M (2009) Voltammetric sensor for glutathione determination based on ferrocene-modified carbon paste electrode. J Solid State Electrochem 13(9):1411-1416

28. Novak I, Šeruga M, Komorsky-Lovrić Š (2009) Electrochemical characterization of epigallocatechin gallate using square-wave voltammetry. Electroanalysis 21(9):1019-1025 
29. Kahl M, Golden TD (2014) Electrochemical determination of phenolic acids at a $\mathrm{Zn} / \mathrm{Al}$ layered double hydroxide film modified glassy carbon electrode. Electroanalysis 26(8):1664-1670

30. Milonjić SK (1999) Surface properties of metal ions modified silicas. Colloids Surfaces A Physicochem Eng Asp 149(1-3):461-466

31. Milonjić SK, Zhigunova LK, Pavasović VL (2007) Adsorption of some weak organic electrolytes from aqueous solutions on silica. Mater Sci Forum 555:195-200

32. Luo J, Cote LJ, Tung VC, Tan ATL, Goins PE, Wu J, Huang J (2010) Graphene oxide nanocolloids. J Am Chem Soc 132(50): 17667-17669

33. Dreyer DR, Park S, Bielawski CW, Ruoff RS (2015) The chemistry of graphene oxide. Graphene Oxide Reduct Recipes. Spectrosc Appl:61-95

34. Chen D, Feng H, Li J (2012) Graphene oxide: preparation, functionalization, and electrochemical applications. Chem Rev 112(11):6027-6053

35. Oldham KB (1998) Voltammetry at a three-phase junction. J Solid State Electrochem 2(6):367-377

36. Scholz F, Schröder U, Doménech-carbó A (2015) Electrochemistry of immobilized particles and droplets. Springer International Publishing
37. Doménech-Carbó A (2015) Theoretical scenarios for the electrochemistry of porous silicate-based materials: an overview. J Solid State Electrochem 19(7):1887-1903

38. Tonle IK, Ngameni E, Tchieno FMM, Walcarius A (2015) Organoclay-modified electrodes: preparation, characterization and recent electroanalytical applications. J Solid State Electrochem 19(7):1949-1973

39. Regulation EP and C (2004) Regulation (EC) No 1333/2008 OF The European Parliament and of the council of 16 December 2008 on Food Additives. In: Euratom

40. Fazary AE, Taha M, Ju YH (2009) Iron complexation studies of gallic acid. J Chem Eng Data 54(1):35-42

41. Hassanien MM, Kenawy IM, Mostafa MR, El-Dellay H (2011) Extraction of gallium, indium and thallium from aquatic media using amino silica gel modified by gallic acid. Microchim Acta 172(1-2):137-145

Publisher's note Springer Nature remains neutral with regard to jurisdictional claims in published maps and institutional affiliations. 